Saudi Journal of Humanities and Social Sciences

Abbreviated Key Title: Saudi J Humanities Soc Sci

ISSN 2415-6256 (Print) | ISSN 2415-6248 (Online)

Scholars Middle East Publishers, Dubai, United Arab Emirates

Journal homepage: https://saudijournals.com

Original Research Article

\title{
Impulse of Decentralisation to Citizen's Participation in the Local Development of Bamenda, Cameroon
}

\author{
${\text { Bongajum Simplice } \text { Ngoran }^{1 *} \text {, Benoit Mougoue }}^{1}$ \\ ${ }^{1}$ Department of Geography, University of Yaounde 1, Yaounde, Cameroon
}

DOI: $\underline{10.36348 / \text { sjhss.2021.v06i04.003 }}$

| Received: 07.03.2021 | Accepted: 04.04.2021 | Published: 13.04.2021

*Corresponding author: Bongajum Simplice Ngoran

\section{Abstract}

The reinforcement of decentralisation in Cameroon through the enactment of the three laws on the orientation of decentralisation in 2004, and the general code of regional and local authorities promulgated in 2019 are instruments geared at augmenting citizen's participation in local development. Despite this enabling legal environment, maximum participation in local development of Bamenda is still a far fetch. In-depth documentation was done to grasp data and information used for analyses and results. Some 1202 questionnaires were distributed to people in Bamenda from all works of life. Semi-structured and open interviews were addressed to key and resource stake holders in the area of study. Results from field findings show that only $55 \%$ of Bamenda inhabitants are aware of projects realised in the locality, just $29.5 \%$ contribute financially, $25.5 \%$ contribute labour wise, and $10 \%$ participate by offering material. Field investigation also revealed that the local population is excluded from follow-up and evaluation of developmental projects. This article makes recommendations to sensitise and mobilise the local population in view of up-lifting citizen's participation in local development.

Key words: Decentralisation, Citizen's participation, local development.

Copyright $\odot 2021$ The Author(s): This is an open-access article distributed under the terms of the Creative Commons Attribution 4.0 International License (CC BY-NC 4.0) which permits unrestricted use, distribution, and reproduction in any medium for non-commercial use provided the original author and source are credited.

\section{I-INTRODUCTION}

The ideologies of the Neoliberals in the 1950s were contradictory to those of the Interventionist Centralised State Ideologists [1,2]. The Neoliberals advocated for the abandonment of bureaucracy and gigantic development plans to embark on the process of decentralisation and share responsibilities to local governments. The move from the Centralised State to liberal organisations marks a turning point in the history of Decentralisation. Though decentralisation as a governance policy started in the Western World, it has

\footnotetext{
1 The neo-liberals were of the opinion that the centralised State of governance could no more sustain the wants and needs of citizens in the 1950s, faced with the devastating economic crisis at that time. In fact, they showed the limits of the Keynesian Interventionist Theory which was very much in support of the role of the Central Government.

2 Ngoran Simplice, B., 2019, "Decentralisation and development of Bamenda City, North West Region, Cameroon". PH.D Thesis, University of Yaoundé I.
}

for over the past three decades infested all continents of the World [3].

Since the late 1980s and the failures of the Jacobin models and structural adjustment policies, decentralization has become a vaunted political priority for many African countries [4]. It is presented as a new avenue for many of them after long years under a centralist regime, a new path for democracy and development. Decentralization is also seen by technical and financial partners, who have often conditioned their aid on it, as a response to the need for a radical reform of the State in order to establish democracy on concrete foundations and to increase citizen participation in development and in decision-making processes. Indeed,

\footnotetext{
${ }^{3}$ Edy Fils, A., 2012, Decentralisation et mise en oeuvre des strategies de developpement local: Analyse du syteme de gouvernance territoriale du cas de croix de bouquets, mémoire de maitrise, Universite d'Etat d'Haiti

${ }^{4}$ General conference on local councils, 2019, Ministry of decentralization and local development, Cameroon.
} 
there is no poverty reduction programme, which is the top priority of the programmes of the governments of African countries that does not compulsorily include decentralization and local development.

Sub-Saharan Africa has also embarked on these administrative reforms inspired by the ideas of modern governance. However, the processes and procedures differ according to the goals and objectives pursued, and depending on the institutional arrangements and implementation mechanisms, and the customary practices of the country-specific secular authorities. Thus, the success of these reforms can depend only on their harmonious integration into the political and cultural, local and national context. With decentralization in Sub-Saharan Africa, the people and leaders are hoping that the entrenchment of grassroots democracy will enable better mobilization of resources for local development, better satisfaction of needs at the local level and, lastly, greater participation of the people in the management of local public affairs. Just as many francophone African countries, even though bilingual, Cameroon has a long history of decentralisation though evolving at the pace of a tortoise.

\section{II- OVER-VIEW OF DECENTRALISATION IN CAMEROON}

Decentralization in Cameroon is a process which started even before the independence of the country [5]. This process is closely linked to the political and institutional development of Cameroon, through successive stages, namely the early stages of decentralization under the mandate and trusteeship regimes (1920 to1959), its difficult appropriation after independence (1959 to 1974) and the harmonization of local affairs management systems after unification (1974 to 1996).
The 18 January 1996 Constitution was a major turning point by establishing the advent of a Decentralized Unitary State. Since then, decentralization has experienced a new upsurge and a significant evolution, notably following the three founding laws of 22 July 2004, on the basis of which powers and resources were devolved to city councils from 2010 onwards. Since then, the decentralization process has made considerable progress, reflecting Government's commitment to pursue and further consolidate this public policy, which is a major option for the Government.

This dynamic concerns the legal framework applicable to decentralization which has been growing at a steady pace over the years, particularly since 2011 . It particularly revealed itself with a relatively consistent and functional institutional system.

However, it should be pointed out that the effective devolution of powers by ministries has been concretized on the ground by major achievements. Accordingly, significant financial allocations were mobilized to support such devolution, improvement of peoples' living conditions and local development actions. Can it thus be said that legally and institutionally, decentralization in Cameroon has been up to expectations?

Synthetically, the answer is that key milestones have been laid, but many instruments still in the process of being finalized need to be enacted, the available legal arsenal needs to be supplemented by new instruments to be drafted and some existing instruments need to be reviewed.

${ }^{5}$ General conference on local councils, 2019, Ministry of decentralization and local development, Cameroon P.25. 


\section{1 Legal and regulatory instruments binding the evolution of decentralisation in Cameroon}

Table-1: Synthetic table of important laws and decrees since 1996 in Cameroon

\begin{tabular}{|c|c|c|}
\hline & Laws/Decrees & Content and remarks \\
\hline 1 & $\begin{array}{l}\text { Law } n^{0} 96 / 6 \text { to review the } \\
\text { constitution of } 2^{\text {nd }} \text { June } 1972, \\
\text { article }\end{array}$ & $\begin{array}{l}\text { Establish Cameroon as a decentralised unitary state. In addition to the } \\
\text { council, the } 1996 \text { constitution established the region as the second level } \\
\text { of decentralisation. It also set up the senate as the upper house of } \\
\text { parliament. }\end{array}$ \\
\hline 2 & $\begin{array}{l}\text { A-Law } \mathrm{N}^{0} \quad 2004 / 17 \text { on the } \\
\text { orientation of decentralisation } \\
\text { B-Law } n^{0} 2004 / 018 \text { to lay down } \\
\text { rules applicable to councils } \\
\text { C-Law } n^{0} \text { 2004/019 to lay down } \\
\text { rules applicable to regions }\end{array}$ & $\begin{array}{l}\text { A-Lays down general rules on decentralisation and reviews the status of } \\
\text { the mayor and reinstates council union. } \\
\text { B-This law also set a new supervisory mechanism and does away with } \\
\text { the old appellations (urban and rural council). } \\
\text { C-This law provide new competences to councils so as to facilitate } \\
\text { development of localities and ameliorate livelihood. }\end{array}$ \\
\hline 3 & $\begin{array}{l}\text { Presidential decree } n^{0} 2007 / 117 \\
\text { of } 24 \text { April bearing creation of } \\
\text { new councils }\end{array}$ & This decree increased the number of councils from 301 to 360 \\
\hline 4 & $\begin{array}{l}\text { Presidential decree } \mathrm{n}^{0} \quad 2008 / 15-16 \\
\text { of } 17 \text { January } 2008\end{array}$ & This decree raised the number of city councils from 2 to 14 \\
\hline 5 & $\begin{array}{l}\text { Law } n^{0} 2009 / 11 \text { to lay down the } \\
\text { financial regime of regional and } \\
\text { local authorities. }\end{array}$ & $\begin{array}{l}\text { This law gave and increase the possibilities and opportunities of council } \\
\text { to increase their yearly financial package and boost development. }\end{array}$ \\
\hline 6 & $\begin{array}{l}\text { Law n }{ }^{0} 2009 / 019 \text { on local fiscal } \\
\text { system }\end{array}$ & $\begin{array}{l}\text { This law maintained the principle of harmonious development of all } \\
\text { regions and local authorities on the basis of national solidarity and inter- } \\
\text { regional balance. Improve transparency and output in local tax }\end{array}$ \\
\hline 7 & 2010 Transfer of competences & $\begin{array}{l}\text { A series of nine decrees signed permitted some ministries to transfer } \\
\text { competences to councils }\end{array}$ \\
\hline 8 & $\begin{array}{l}\text { Decree } \mathrm{n}^{0} 2013 / 159 \text { of } 15 \text { May } \\
2013 \text { bearing special public } \\
\text { administrative financial control }\end{array}$ & $\begin{array}{l}\text { This decree permits public finances to undergo adequate control and } \\
\text { serve the purpose for which it is intended to serve }\end{array}$ \\
\hline 9 & $\begin{array}{l}\text { Decree } \mathrm{n}^{0} 2013 / 031 \text { of } 13 \\
\text { February to lay down organisation } \\
\text { and functioning of national civil } \\
\text { status registry }\end{array}$ & $\begin{array}{l}\text { This decree will permit the harmonisation of civil status all over } \\
\text { Cameroon such that a unique register for all Cameroon will be possible }\end{array}$ \\
\hline 10 & $\begin{array}{l}\text { Law no } 2019 / 024 \text { of } 24 \text { December } \\
2019 \text { to lay down the general code } \\
\text { of regional and local authorities }\end{array}$ & $\begin{array}{l}\text { This law is a combination of the three laws of } 2004 \text { and the fiscal regime } \\
\text { law of } 2009 . \text { It makes the legal environment more fluid. }\end{array}$ \\
\hline
\end{tabular}

Source: Better understanding decentralisation's practical guide by GIZ, 2013

For any Decentralisation process to be successful, it necessitates constant amelioration of the legal environment, the adhesion and participation of all the actors involve in the process. From central Government institutions to the local population, direct beneficiaries of the process.

The General code [6] of local and regional authorities in its section 40 (1) stipulates that any natural or legal person may propose to the council or regional executive any measures aimed at fostering the development and/or improving the functioning of the local authority concerned. In section 40 (2) the code gives the right to any inhabitant or tax payer of a local authority to request at his expense the disclosure or

\footnotetext{
${ }^{6}$ The general code of regional and local authorities was promulgated on the $24^{\text {th }}$ of December 2019
}

obtain a complete or partial copy of the reports of deliberative organs, the budget, draft, and annual performance reports development plan, accounts or orders, under the conditions laid down by regulation. Section 41 of the code also stipulates that associations, local civil society organisations, village and quarter committees contribute to the realisation of regional and local authority's objectives and missions.

\section{III- REVIEW OF CONCEPTS}

Concepts such as decentralisation, citizen participation and development, which are pertinent to this analysis, reveal a variety of meaning and purposes since scholars in social sciences define and interpret them in different ways [7].

7 Sharma, K., 2000, 'Popular Participation in Botswana', in United Nations (UN), Decentralisation 


\section{III-I Decentralisation}

The word decentralisation varies according to authors and conceptions. In the present study decentralisation is;

- Section 5(1) [8] of the general code of Regional and Local Authorities defines decentralisation as the devolution by the State of special powers and appropriate resources to local authorities. Section 5 (2) stipulates that Decentralisation shall constitute the basic driving force for the promotion of development, democracy and good governance at the local level.

- Joseph Owona [9], defines decentralization as a method of organization of the administrative arm of government in which the state creates decentralized public entities and grants them jurisdiction and resources while preserving the supervisory and monitoring power. It is a means of developing democracy and specifically local democracy, closer to citizens. Decentralisation comes with an institutionalization of administrative and financial control.

- Benoit M [10], defines decentralisation as the transfer of public prerogatives from higher to lower levels of governance. The author also says decentralisation is a tool that fosters local development, governance and democracy.

- Hussein [ 11 ], says administratively, decentralisation is an important process that allows decongestion of the central government and reduces the workload to manageable proportions. The breaking-up of the workload promotes greater efficiency, coordination and effectiveness in public service delivery. Since decision-making powers are transferred from the centre to local institutions decentralisation provides an opportunity for local involvement in decision-making and harnessing local knowledge, resources and expertise in the development process.

and Citizen Participation in Africa, Regional Development cited by Emmanuel Innocents Edoun,2009

${ }^{8}$ General Code of Regional and Local authorities, December 2019.

9 Joseph,O,. 2012, Decentralisation in Cameroon, Harmattan.

${ }^{10}$ Benoit, Mougoue,. 2011, Participation populaire au developpement local dans le bassin versant de la Mingoa a Yaounde (Cameroun) al' ère de la décentralisation, HDR, Universite Michel de Montaigne Bordeaux 3.

${ }^{11}$ Hussein Lufunyo, 2015 Decentralization and Human Resource Development; Documented Challenges in Local Government Authorities in Tanzania

\section{III-2 Citizen participation}

No matter the angle of attack, participation in the realm of decentralisation entails the coming together of different stake holders to achieve a common goal.

- Benoit M, 2011 [12] defines participation as that relationship that involves at least two parties with compatible objectives and aimed at working together, part-take in risk taking, results, profits or losses. This relationship implicates the consideration of both parties in decision making, power sharing, advantages and responsibilities. In such a relationship, both parties have something to offer.

- Checkoway and Van Til 1978 [13], the term 'citizen participation' is a multidisciplinary one, and falls into four major areas of democratic theory, namely, political behaviour, community development, citizen action and government initiated citizen action, there are variations in terminology and definitions. For instance, terms like popular participation, community involvement, public participation and citizen participation are often used. However, in this analysis the term 'citizen participation' is preferred because of its relevance to the Cameroonian context. In addition, there is common agreement that citizen participation entails an active process in which participants take initiative and action in purposeful activities in relation to a local institution or area of which they are citizens or legal residents.

Citizen participation, according to Devas and Grant [14], is the way in which citizens exercise influence and control over the decisions that affect them. Citizen participation is increasingly becoming a core aspect of decentralization reforms which according to Rondinelli [15] entails 'the transfer of authority and responsibility for public functions from the central government to subordinate or quasi-independent

${ }^{12}$ Benoit M, 2011, P 30-34.

${ }^{13}$ Checkoway, B. and Van Til, J., 1978, 'What Do We Know about Citizen Participation? A Selected Review of Research', in Langton, ed.,

${ }^{14}$ Devas, N. and Grant, U., 2003. Local Government Decision-Making - Citizen Participation And Local Accountability: Some Evidence From Kenya And Uganda. Public Administration and Development, 23, 307-316 (2003) [Online] 28 July 2003. Available at http://onlinelibrary.wiley.com/doi/10.1002/pad.281/pdf [Accessed

November 18, 2020].

${ }^{15}$ Rondinelli, D., 1999. What is Decentralization? In: Litvack, J., \& Seddon, J., 1999. Decentralization Briefing Notes. World bank Intitute working Papers. Pp. 2-5. [Online] Available at http://www wds.worldbank.org/servlet

/WDSContentServer/WDSP/IB/1999/11/04/00009494. 6_99101505320840/Rendered/PDF/multi_page.pdf [Accessed November 21, 2020]. 
government organizations or the private sector'. In this context, participation can be direct or indirect.

One of the main objectives of this paper is to evaluate that, Citizen Participation contributes to local economic development through decentralised structures such as the council, city council and regional council. Citizen participation emphases people's direct involvement in the decision making process. Christenson [16] characterised citizen participation as highly motivating politically and believe citizens will participate fully and continually in local economic development. He also views it as very efficient as citizens are able to communicate their political views to others and debate them effectively.

\section{III-3 Local Development}

One of the major challenges of the ongoing decentralization processes in Sub-Saharan Africa is to establish a system of representation that is closer to the people [17]. This process promotes local development and better service delivery to the population and creates new actors known as local authorities. They are at the centre of the challenge to promote regional development and the emergence of our countries.

The concept of local development features prominently in many development discourses, especially the eradication of poverty through wealth creation and emergence in Sub-Saharan Africa, is it through local actors or international development partners.

Generally, local development "is first and foremost a more or less concerted economic and social, or even cultural impetus driven by individual and collective actors in a given area" [ 18 ]. More specifically, it is "a process that makes it possible to nurture priorities, to select actions based on the knowledge and proposals of the population groups living in a given area and to use available resources to meet the said proposals" made by all local actors. From this viewpoint, local development "encourages the prioritization of actors rather than infrastructure and networks rather than established institutions in order to give the men, women and groups directly concerned a decision-making role on the actions they undertake".

\section{PRESENTATION OF STUDY AREA}

Bamenda is located in the North Western plateau of Cameroon and is the Capital city of the North
West Region. The city is situated $366 \mathrm{~km}$ North West of the administrative capital of Cameroon, Yaounde and about $450 \mathrm{~km}$ of Cameroon's economic capital, Douala. Bamenda is known for its cool climate and scenic hilly location. Bamenda also doubles as the capital of the North West Region and Mezam division.

According to the 2005 population and housing census in Cameroon, the population of the North West Region was estimated at 1.728953 inhabitants. That of Bamenda was estimated to be 322889 inhabitants out of which the urban population constituted 269,530 while sub urban population was estimated at 53,359 inhabitants. Evaluation of the 2005 population and housing census revealed that $18.6 \%$ of the population of North West region lives in Bamenda. The surface area of Bamenda city is estimated at $1076 \mathrm{~km}^{2}$ with a population density of 300 inhabitants per square kilometer.

Bamenda city is located between latitude $6^{\circ} 5^{\prime} 2^{\prime} ' \mathrm{~N}$ and latitude $6^{\circ} 6^{\prime} 4^{\prime}{ }^{\prime} \mathrm{N}$ and longitude $10^{\circ} 0^{\prime}$ and $10^{\circ} 31^{\prime} \mathrm{E}$ of the Greenwich meridian. The city is situated in the western highlands of Cameroon at an altitude of $1230 \mathrm{~m}-1510 \mathrm{~m}$. Bamenda city council regroups three sub divisions namely Bamenda I (Bamendankwe), Bamenda II (Mankon) and Bamenda III (Nkwen).

Bamenda is bordered to the North by the Bafut sub division, to the North West by the Momo division, to the South by the Santa sub division and South West by the Bali sub division. To the west the city is bordered by the Tubah sub division.

${ }^{16}$ Christenson, R.M, Ideology and Modern Politics (1971)

${ }^{17}$ General conference on local councils 2019 edition, Cameroon P.11.

${ }^{18}$ Ibid p. 11 


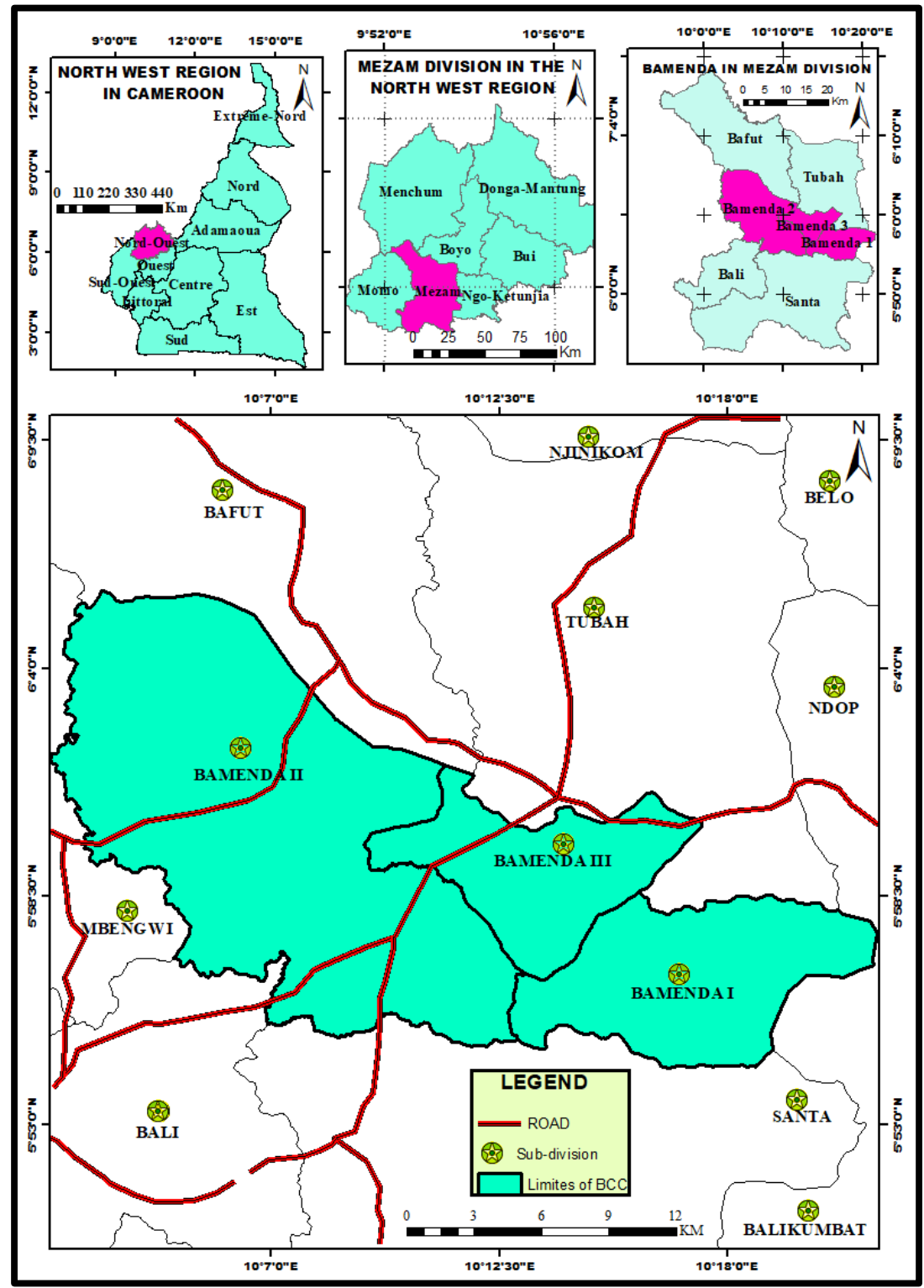

Fig-1: Bamenda City and neighbouring Sub-Divisions

\section{METHODOLOGY OF DATA AND INFORMATION COLLECTION}

This article made use of secondary data as well as primary data sources. Concerning secondary data sources, research works were consulted in university libraries, specialised documentation centres, regional development institutions, international cooperation institutions and Non-governmental institutions. Council reports and those of Bamenda city council were also exploited. The print and audio-visual media as well as the internet sources were also explored.

Primary data sources concerned observations, interviews, and focus group discussion and household survey procedures. Observations included direct observation and participant observation. The type of interview used was structured in depth interviews. According to Nlep (2001), a structured interview involves one person asking another person a list of predetermined questions about a carefully-selected topic. It enables the researcher to examine the level of understanding a respondent has about a particular topic - usually in slightly more depth than a questionnaire. Resource and key persons interviewed included mayors, divisional officers, heads of N.G.O's and associations and councillors. Two focus group discussions were also organised involving mainly the local population. This permitted the study to confront the views of the beneficiary population on the impulse of decentralisation in local participation to enhance local development.

The bulk of the information was obtained from questionnaire sampling. In an attempt to weigh the contribution of citizen's participation to council initiated projects, responses were retrieving from 1202 questionnaires sampled to households (table 2). 
Table-2: Questionnaire response rate

\begin{tabular}{|l|l|l|l|}
\hline Sub division & No of questionnaire administered & No of questionnaire retained for analysis & $\begin{array}{l}\text { Response rate } \\
(\boldsymbol{\%})\end{array}$ \\
\hline Bamenda I & 104 & 99 & 7.80 \\
\hline Bamenda II & 736 & 702 & 55.36 \\
\hline Bamenda III & 425 & 400 & 31.54 \\
\hline Total & $\mathbf{1 2 6 8}$ & $\mathbf{1 2 0 2}$ & $\mathbf{9 4 . 7} \%$ \\
\hline
\end{tabular}

Source: Field work, 2016

\section{VI- PRESENTATION OF FIELD FINDINGS}

The councillors [19] of Bamenda city coin projects with the consent of the local population and communicate this to the council. In some cases, the people make small financial contributions towards the realisation of projects, such contributions are given to the council which completes the amount set to realize the project. All councillors act as representatives of individuals and groups within their area of responsibility. They are a source of information or point of access to other agencies. Often through regular contact sessions with constituents of their ward, community leaders, build relationships with key individuals or groups within their individual wards (quarters) and Policy makers. Attending council sessions on issues such as budget settings, adoption of council accounts, social services, schools, planning and the environment are statutory. These meetings involve debating and approving proposals, as well as decisionmaking.

The local population of Bamenda as well as other partners are involved in the identification, implementation and follow up and evaluation phases of projects.

\section{VI-I Participation of the local population in the need identification phase}

In the project cycle, identification of needs is very important to overcome problems or fulfil the development priorities in the context of local objectives [20]. As the development projects affect the lives of local people, local people's participation in this stage is of utmost importance. It is the local people that knows the nature of their problems and may know the way of overcoming such problems. So, the project idea and possible solution must emanate from initiatives of the local people.

\section{VI.I.I Consultations and communication with the local population}

At the Need Identification phase, municipalities ensure peoples' participation by

19 Councillors, who are elected representatives of the villages that make up the municipality.

20 Ngega venessa, 2014 Municipal councils and participatory rural development in cameroon: the case of bamenda iii municipal council, masters memoire, IRIC Yaounde. consulting with the population indirectly through the councillors, who are elected representatives of the villages that make up the municipality. The councillors then organise planning meetings with the traditional authorities and quarter heads to know the interest of the people of the various quarters. From this, they can design projects for the quarter following the priority needs expressed by the people. The council also works in collaboration with the Traditional Development Council (TDC). The TDC is foremost in informing the council on the priority needs of the local people of the various quarters. Also, the municipalities work in collaboration with the traditional rulers. The "Fons" are custodians of tradition in their village and so take care of all matters related to development. The traditional authorities in these municipalities are strongly respected and they usually work in collaboration with their people. The councils consult the traditional rulers often on development matters as they also directly represent the local population from another dimension.

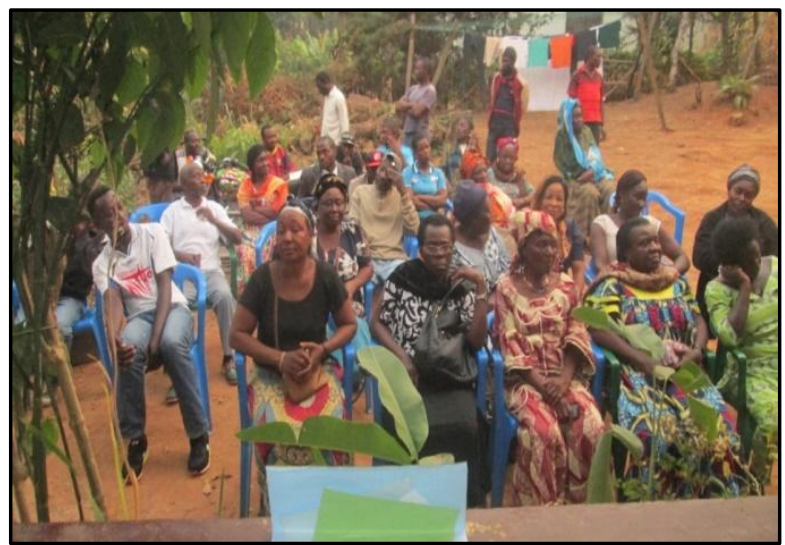

Photo-1: Meeting in Nkefu quarter to brainstorm on priority projects

Photo Asangbe2014

Photo 1 shows women on the frontline to brainstorm on projects to be realised. The women are real decision makers in the Bamenda I municipality.

In Bamenda, 55\% (figure 2) of the inhabitants ascertained that there is effective communication between the councillors and the local population in the need identification phase of the different projects locally realised. On the contrary, $40 \%$ decried the nonexistence of accurate communication between the councillors and the local population. Such inhabitants said it was a total blow to local development when the 
priorities of the people concerned are not taken into consideration. Lastly, 5\% had no idea on the communication level between the two parties

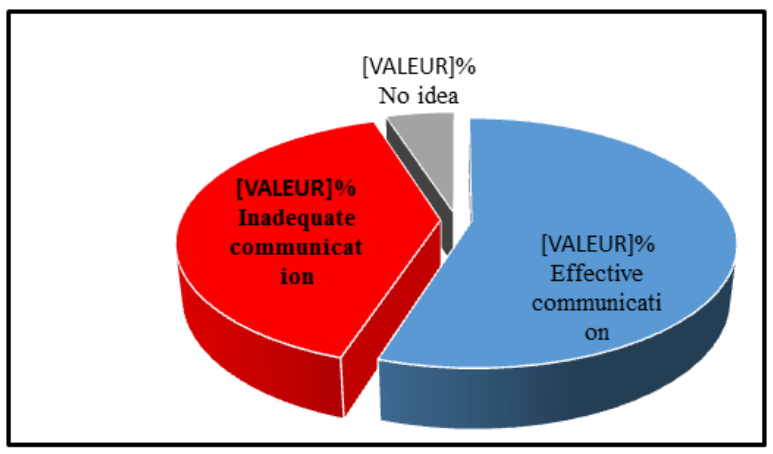

Fig-2: Level of communication between councillors and local population in need identification phase Source: Field work, 2016

\section{VI-2 Participation of the local population in project implementation phase \\ Implementation is perhaps the most vital} stage of the project cycle involving the procurement of equipment and resources, recruitment of personnel and allocation of tasks and resources within the project organization. Under the project implementation plan, resources are mobilized, activities determined and control mechanism established so that the project inputs can produce project outputs in order to achieve the project purpose. Hence local people's participation at this stage is conducive for the successful operation of projects.
At the implementation phase, the people of the beneficiary quarters often pull together resources especially through financial contributions for the realization of a particular project. Often, these contributions are channeled to the council through the TDC of the quarter concerned who may complete the amount to realize the project.

\section{VI-2.1 Financial contributions of the local population to project implementation}

In order to encourage the local people to contribute financially to support projects, each quarter or at times village usually designate a committee in charge of collecting funds. A fix amount is usually decided by the local population. The possibility is given for everyone to contribute according to his capacity at any point in time. Meaning for a total amount of 5000 FCFA, a participant has the possibility to pay his contributions to the committee in installments until the required amount is completed. An informant in Bamenda I Council informed the researcher that each time she has to contribute for a project to be realized in her village, she always gives to the committee any amount she has until completion of the amount demanded. Recently, some of the financial committees have adopted electronic approach in the collection of money for projects. The use of mobile money accounts notably from the MTN and Orange telecommunication companies is recurrent. Some of the city dwellers do contribute for project realization even when out of Bamenda through this electronic money transfer means.

Table-3: Financial contributions of local population to project realisation

\begin{tabular}{|c|c|c|c|c|c|}
\hline \multirow{2}{*}{ Council } & \multirow{2}{*}{ Number sampled } & \multicolumn{2}{|c|}{ Contributors } & \multicolumn{2}{|c|}{ Percentage (\%) } \\
\hline & & yes & No & Yes & No \\
\hline Bamenda I & 99 & 35 & 64 & 3 & 5.32 \\
\hline Bamenda II & 702 & 187 & 515 & 15.5 & 42.84 \\
\hline Bamenda III & 400 & 133 & 277 & 11 & 23 \\
\hline \multirow[b]{2}{*}{ TOTAL } & \multirow[b]{2}{*}{1202} & \multirow[b]{2}{*}{354} & \multirow[b]{2}{*}{856} & 29.5 & 70.5 \\
\hline & & & & \multicolumn{2}{|c|}{100} \\
\hline
\end{tabular}

Source: Field work, 2016

The local population residing in the sub-urban and rural areas contributes more to project realization than those in the urban areas. It is realized that $29.5 \%$ of inhabitants contribute to project realization against $70.5 \%$ who reside in towns. This disparity is explained by the weak social cohesion in the city center and the low powers detained by quarter heads. Contrarily in the suburban and rural areas the level of participation is relatively high due to high social cohesion and solidarity.

\section{VI-2.2 Labour provision of the local population to project implementation}

Given that most people in Bamenda especially those around sub-urban/rural areas are low income earners, they mostly provide manual labour to realize the different development projects initiated by the Municipalities. For instance, the rural/sub-urban people are very instrumental in providing labour for digging and maintaining roads within the quarters (photo 2). The local people do not hesitate to provide labour for projects because these roads lead them from their farms to the markets, making it easy for them to transport their agricultural products to the urban areas and neighbouring villages. 


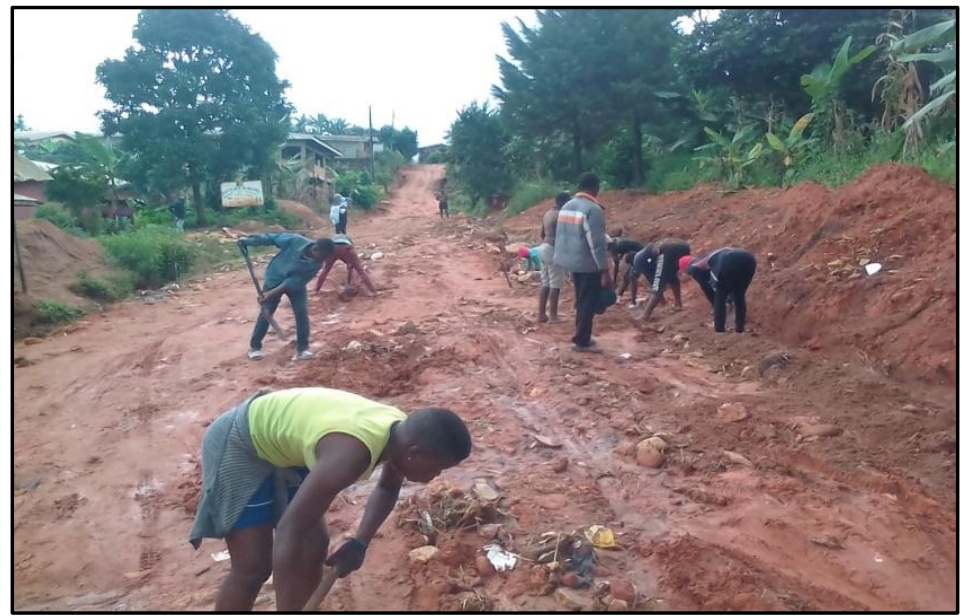

Photo-2: Labour provided by local population during projects

At times parents who are occupied during the realization of projects delegate their children to replace them. During the realization of some projects, the local population contributes by giving material for the realization of the said projects. These materials include sand, stones, gravel, water, planks, etc.

Table-4: Labour provision by the local population for project realisation

\begin{tabular}{|l|r|r|r|r|r|}
\hline \multirow{2}{*}{ COUNCIL } & \multirow{2}{*}{ Respondent Sampled } & \multicolumn{2}{|c|}{ Participation } & \multicolumn{2}{|c|}{ Percentage (\%) } \\
\cline { 3 - 6 } & & \multicolumn{2}{|c|}{ Yes } & \multicolumn{1}{|c|}{ Yo } & \multicolumn{2}{c|}{ Yes } \\
\hline Bamenda I & 99 & 30 & 69 & 2.5 & 5.75 \\
\hline Bamenda II & 702 & 171 & 531 & 14.5 & 44.55 \\
\hline Bamenda III & 400 & 101 & 299 & 8.5 & 24.85 \\
\hline & & & & $\mathbf{2 5 . 5}$ & $\mathbf{7 4 . 5}$ \\
\cline { 3 - 6 } TOTAL & $\mathbf{1 2 0 2}$ & $\mathbf{3 0 2}$ & $\mathbf{9 0 0}$ & & $\mathbf{1 0 0}$ \\
\hline
\end{tabular}

Source: Field work, 2016

During project realization in the Bamenda municipalities, especially projects realized in the suburban space, $25.5 \%$ of the population participates by providing labour on the project site.

\section{VI-2.3 Material provision by the local population during project implementation}

Some inhabitants during project realization contribute materially. Some of such people might not be financially able at the time of project realization, or again after they might have contributed financially and technically they still give some material contributions. These materials include sand, stones especially granite that is very present in the area, trees and planks.

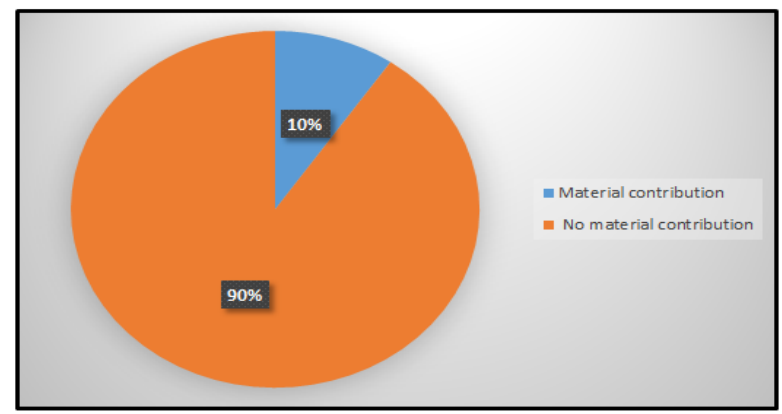

Fig-3: Material contribution of the local population to realization of projects initiated by Councils Source: Field work, 2016
Field evidence shows that $10 \%$ of inhabitants have at least once contributed materially in the realization of a council project. On the other hand, $90 \%$ of inhabitants have never contributed any form of material.

\section{VI-3 Monitoring and Control}

The purpose of monitoring and controlling of a project is to evaluate project performance by providing timely information and feedback to the management from all levels helping the project management to achieve the target of the project.

To ensure peoples' participation at the monitoring and control phase, the municipalities commissions councilors to monitor projects in their area of responsibility and give reports of any mishap during council meetings. The council commission's resource persons such as quarter head to give reports on the functioning of the projects in their quarters.

\section{VI-4 Evaluation and Follow-up}

The final stage of the project cycle is evaluation, which is enhanced by follow-up action.

Evaluation may be done by different people, concerned agencies, and donors of the project on basis to assess the performance of the project to see whether its stated 
objectives are achieved or not and the extent to which it is done.

At this phase, in order to promote public participation, the Bamenda III municipalities have websites for publication of information and development actions of the councils. Notices on Council actions are also published on the council premises. This information is provided for the public to be able to see the various projects initiated by the councils so that they can be able to assess the performance of these projects and determine the extent it has met its stated objectives. At this level, it is revealed that the other stakeholders of development like the central government and, donor agencies ensure follow up of projects. It is not easy for local people to be involved at this stage because the public is hardly provided with updated information concerning the development projects. Also, the councils do not find it necessary for local people to be involved in follow-up of projects so they hardly encourage them to do followup.

\section{VII- DISCUSSION}

Population participation is a central point in the effectiveness of decentralization at the local level. If the population does not participate in all aspects of the project cycle, then decentralization has no meaning. This study conducted in Bamenda city shows the level of the local population's participation in the project cycle.

In identifying projects to be realized in the municipalities of Bamenda, only $55 \%$ of the population does communicate with the intermediaries of the Councils who are councilors. This signifies that almost half of the population does not give their views on projects that are to be prioritized. This also explains why there are mix feelings amongst the population of Bamenda when it comes to appreciating projects realized. Or some of the projects are simply just abandoned by the local population after their realization.

Just $29.5 \%$ of Bamenda inhabitants contribute financially for realization of council projects. This makes some projects realization very difficult because some of such projects are budgeted with the financial contributions of local population taken into consideration, usually to a tune of $5-10 \%$ of the total cost of the project. This has accounted for the mid-way abandonment of some projects. Or it takes a more lengthy time than previewed in the programming of realization of most projects. Concerning labour provision, $25.5 \%$ dwellers do offer their personal labour or send their children to offer both skilled and unskilled labour for projects to be realized. When it comes to monitoring, follow-up and evaluation the local population are completely absent from the chain. This goes a long way to slow the pace of council projects realisation.

From the above discussion, it is realized that the participation of the local population in decentralization is still at its embryonic stage. This stipulates that efforts are to be made to draw the attention of the local population to effective participation in project realization.

\section{VIII-RECOMMENDATIONDS AND CONCLUSION}

There are high expectations among policymakers and enlightened citizens for an increased public role in development and governance. As observed by (A. Venter 2001), the citizens are looking forward to genuinely taking part in the decision making process on matters that concern their welfare. The basic elements of good governance that were absent in Cameroon during the centralized era, are to be actualised through the decentralisation process.

Decentralisation historically evolved to bring decision making power to levels closest to the citizens in order to enable them participate actively and have influence over the decisions made. Popular participation is enhanced if citizens are sensitised, are given information and their self-confidence to hold leaders accountable is developed. The policy actions to enhance participation include;

(i) Establish village development committees, as community structures to interface with local technocrats in articulating and translating local people's needs into action plans;

(ii) Ensure that qualified Rural/Community Development facilitators are deployed at lower administrative levels to work as Village Development Facilitators. Ensure that they are appropriately equipped to work harmoniously with local people, and political leaders;

(iii) Ensure that local planning is results-focused and evidence-based, taking into consideration the locally available resources and capacities;

(iv) Establish local development support funds to assure reliable financing for local development projects;

(v) Establish institutional structures and systems to foster bottom-up and top-down coordination of multi-sectoral development planning, monitoring and evaluation, so that all stakeholders' needs, priorities and views are incorporated in the formulation and implementation of local development plans. Ensure regular joint reviews and evaluations.

(vi) Develop tools for area-based planning to enable each district or locality to have its own baseline, understand its strengths and weaknesses, and 
develop its own local vision within the wider national vision;

(vii) Put in place mechanisms to mobilise and ensure community contribution to foster local ownership of development programs.

(viii) The Government will establish appropriate coordination and partnership development mechanisms to enhance active participation of all stakeholders, especially non state development actors (NGOs, Cooperatives, donors, private sector organisations, etc) in decentralisation processes.

(ix) Put in place mechanisms to ensure that CSOs and private sector representatives participate in local development planning processes, Provide incentives (including regulatory measures) to encourage partnership8 between local governments and non-state actors and establish local platforms and guiding instruments for stakeholder engagement in decentralisation

Decentralisation as defined earlier is a process that gives roots to democracy. It is a process where the transfer of power and resources to the local level will help to empower communities to work together to define and resolve their problems [14]. Decentralization is a complex process. The process of attaining decentralisation objectives, including the promotion of participatory approaches to development by local institutions such as the councils, city council, and regional council largely depends on what is happening within the local government sector and at the national level [18].

\section{REFERENCES}

1. Benoit, M. (2011). Participation populaire au developpement local dans le bassin versant de la Mingoa a Yaounde (Cameroun) a l'ère de la décentralisation, HDR, Universite Michel de Montaigne Bordeaux 3.

2. Checkoway, B., \& Van, Til, J. (1978). 'What Do We Know about Citizen Participation? A

3. Checkoway, B., \& Van, Til, J. (1978). 'What Do We Know about Citizen Participation? A Selected Review of Research', in Langton, ed.,

4. Christenson, R.M, Ideology and Modern Politics. (1971).

5. Devas, N., \& Grant, U. (2003). Local government decision- making - citizen participation and local accountability: some evidence from Kenya and Uganda. Public Administration and Development:
The International Journal of Management Research and Practice, 23(4), 307-316.

6. Edy, Fils, A. (2012). Decentralisation et mise en oeuvre des strategies de developpement local: Analyse du syteme de gouvernance territoriale du cas de croix de bouquets, mémoire de maitrise, Universite d'Etat d'Haiti

7. General Code of Regional and Local authorities, December 2019.

8. General conference on local councils. (2019). Ministry of decentralization and local development, Cameroon. government Management and Development, Hamburg: Institute fur Africa-Kunde

9. Hussein, L. (2015). Decentralization and Human Resource Development; Documented Challenges in Local Government Authorities in Tanzania initiatives: Self Governance, Decentralization and Accountability, Rotschild, D.(ed) of the Republic of South Africa, 1996 (Act 108 of 1996)

10. Joseph, O. (2012). Decentralisation in Cameroon, Harmattan.

11. Ngega, V. (2014). Municipal councils and participatory rural development in cameroon: the case of bamenda iii municipal council, masters memoire, IRIC Yaounde

12. Ngoran, S. B. (2019). "Decentralisation and development of Bamenda City, North West Region, Cameroon". PH.D Thesis, University of Yaoundé I.

13. Olowu. (1994). Beyond the failure centralized state in Africa. Strengthening African Local

14. Oyono. (2004). Cameroon: The Way Forward for Good Governance

15. Oyugi, W.O. (2000). 'Decentralisation for good governance and Development', Constitution

16. Reddy, P.S. (1996). Local government restructuring in South Africa. Readings in Local

17. Rondinelli, D. (1999). What is Decentralization? In: Litvack, J., \& Seddon, J., 1999. Decentralization Briefing Notes. World Bank Intitute working Papers. 2-5. [Online] Available at http://www wds.worldbank.org/servlet /WDSContentServer/WDSP/IB/1999/11/04/000094 94.6_99101505320840/

Rendered/PDF/multi_page.pdf [Accessed November 21, 2020].Selected Review of Research', in Langton, ed.,

18. Sharma, K. (2000). 'Popular Participation in Botswana', in United Nations (UN),Decentralisation and Citizen Participation in Africa, Regional Development cited by Emmanuel Innocents Edoun. 